\title{
Harita Disiplininin Çeşitli Kademelerindeki Programlarına İlişsin Öğretim Materyali Geliştirme
}

\author{
Yakup Emre ÇORUHLU ${ }^{1 *}$, Emre KARAAGAÇ²
}

\section{$\ddot{O ̈ z}$}

Haritacılık Dünya'nın en eski mesleklerinden biridir. Son yıllarda hızlı şekilde gelişen teknolojik imkânlar ile haritacılık uygulamaları bilişim teknolojilerine doğru yönelmektedir. Bu sektördeki insan kaynağını yetiştiren eğitim kurumlarında ise bilgi genellikle klasik anlatım yöntemi ile verilmektedir. Öğretmen merkezli olan bu yaklaşım öğrenmede yetersiz kalmaktadır. Öğrenci merkezli ve öğrencinin daha aktif olduğu bir eğitim ortamı ile geliştirilen ders materyalleri öğrencilerin daha iyi yetişmesine katkı sağlayacaktır. Bu amaçla çalışmada öncelikle uygulama yapılacak ortaöğretim kurumu belirlenmiş, ortaöğretim, ön lisans ve lisans seviyelerinde verilen dersler ve bu derslerin öğretim strateji, yöntem ve tekniklerle ilişkileri kurulmuştur. Örneklem grubu oluşturularak öğrencilerin eksik olduğu konular belirlenmiştir. Bu öğrencilerin mevcut bilgi eksikleri sınav analizleri ile ortaya çıkartılmış, eksiklikleri gidermek için materyaller geliştirilmiş ve uygulanmıştır. Buna ilaveten performansa dayalı farklı ölçme değerlendirme araçlarıyla materyallerin beceri kazandırma düzeyleri belirlenmiş̧ir. Sonuç olarak çalışma ile geliştirilen materyallerin, ilgili konular hakkında öğrencilerin becerilerini arttırdığı gözlemlenmiştir. Bu bağlamda, derslerin öğretim strateji yöntem ve tekniklerine uygun olarak planlanması ve işlenmesi, öğrencilerin bilgi eksikliklerinin farklı ölçme ve değerlendirme araçları ile tespit edilmesi, öğrencilerdeki bilgi eksikliklerinin giderilmesi için materyal geliştirilmesi, derslerin işlenmesinde ve materyallerin uygulanmasında öğrenci merkezli yaklaşım benimsenmesi, önerilmektedir.

Anahtar Kelimeler: Haritacılık, öğretim tekniği, bilgi eksikliği, materyal geliştirme

\section{Developing Instructional Material Related to the Programs of Various Levels of Geomatics Discipline}

\begin{abstract}
As one of the oldest professions of the world, geomatics is evolving towards information technologies with rapidly developing technological opportunities in recent years. In the educational institutions that train human resources in this sector, classical expression method is mostly used. This teacher-centred approach is inadequate in learning. However, a student-centred and more active educational environment and course materials developed in this environment will make a great contribution to the better upbringing of students. For this purpose, firstly the secondary education institution to be applied was determined, the courses given at secondary, associate and undergraduate levels and the relations of these courses with instructional strategies, methods and techniques were established. A sample group was formed to identify the missing students. Existing knowledge deficiencies of these students were revealed by exam analysis, materials were developed and applied to eliminate deficiencies. Then, the skill acquisition levels of the materials were determined with different measurement and assessment tools based on performance. As a result, it was observed that the materials developed by the study increased the students' skills about the related subjects. In this context, it is recommended that planning and processing of courses in accordance with instructional strategy methods and techniques, determination of students' information deficiencies with different measurement and evaluation tools, development of materials for the elimination of information deficiencies in students, adopting a student-centred approach in the processing of courses and application of materials.
\end{abstract}

Keywords: Geomatics, teaching technique, lack of knowledge, material development

\footnotetext{
${ }^{12}$ Karadeniz Teknik Üniversitesi, Mühendislik Fakültesi, Harita Mühendisliği Bölümü, Trabzon, Türkiye, yecoruhlu@ktu.edu.tr, karaagacemre@gmail.com
}

${ }^{1}$ https://orcid.org/0000-0002-8673-603X ${ }^{2}$ https://orcid.org/0000-0002-5246-5219 


\section{Giriş}

Arazi feodalizm dönemlerinde sadece mali değeri olan bir zenginlik kaynağı iken günümüzde bilindiği üzere kıt bir kaynak haline gelmiştir (Çoruhlu vd., 2021; Başer vd., 2016). Bu kıt kaynağı en iyi şekilde işleyen haritacılık, ilk çağlardan beri modern dünyanın gereksinimlerine cevap verebilen dünyanın en eski bilimlerinden biridir ve konuma dayalı veriler ürettiğinden disiplinlerin ara kesitinde önemli bir yere sahiptir. Bu konumundan dolayı geniş bir yelpazede uygulama sahası vardır. $\mathrm{Bu}$ anlamda harita hayattır sloganı insan hayatının vazgeçilmez veri kaynağı olması adına ifade edilmiş yerinde bir söylemdir (Başer vd., 2011).

Günümüzde, harita sektörü yetişmiş insan gücünü farklı seviyelerdeki eğitim kurumları sayesinde yetiştirmektedir. En temel eğitim kurumu, ortaöğretim seviyesinde meslek lisesi içindeki harita tapu kadastro alanında verilmektedir. Bu eğitim seviyesi Mesleki Yeterlilik Kurumu dördüncü seviyesine denk gelmektedir. Ardından üniversitelerin meslek yüksekokullarında Ön lisans olarak harita ve kadastro programı ile verilen eğitim beşinci seviye, harita mühendisliği lisans programı ile verilen eğitim 6. seviye olarak tanımlanmaktadır (Yıldırım ve Başer, 2020).

Tarihsel süreç içerisinde eğitimin tanımı kişilere, dönemlere, ülkelere ve felsefelere göre farklılıklar göstermektedir. Eğitim; bireyin davranışlarında kasıtlı olarak ve kendi yaşantıları yoluyla istendik davranış değişikliği meydana getirme sürecidir (Ertürk, 1972). Günümüzde psikolog ve eğitimcilerin büyük bölümü öğrenmeyi, yaşantı ürünü kalıcı izli davranış değişikliği olarak tanımlamaktadır. Öğrenme, eğitim almış bir kişinin bir şeyi bilme veya yapabilme durumu olarak nitelendirilebilir. Bu bağlamda öğrenme için formal veya informal bir eğitim gereklidir (Erden, 1997). Diğger taraftan öğretme, öğrenmeyi sağlama etkinliklerine denir. Öğretme faaliyetinin gerçekleşmesi için bilgiye sahip olan kişi veya kaynak ile bilgiye ihtiyaç duyan bir kişinin varlığ yeterlidir. Benzer şekilde öğretim ise öğretme faaliyetlerinin okullarda yapılan planlı ve kontrollü haline denir. Öğretme faaliyeti bilgi sahibi olan her insan tarafından yapılabildiği halde, öğretim faaliyetini gerçekleştirmek ise yalnızca öğretmenler tarafından yapılmaktadır (Çepni vd., 2008). Güncel ve yeni hazırlanan öğretmen eğitimi programlarının teoriye dayalı öğretmen merkezli yaklaşım yerini uygulamaya dayalı öğrenci merkezli yaklaşıma bırakmıştır. Bu durum öğretim yöntem ve tekniklerinin daha aktif kullanılması gerektiğini gösterir (Oddens, 2004; Kılıç ve Acat, 2007).

Eğitim öğretim alanında öğretim yöntem ve teknikleri ile materyal kullanımı öğrenme ortamının iyileştirilmesine son derece katkı sağlamaktadır. Zamanla değişen ve gelişen teknolojiyi de göz önüne alarak haritacılık alanında da bu yöntem ve tekniklerin kullanılması, öğrencilerin yaparak ve yaşayarak öğrenmelerini sağlayacaktır. Yapılan çalışmalarda görülmektedir ki, daha çok duyu organına hitap eden öğrenme, daha kalıcı etkilere sahiptir. Öğrenmede etkin olan duyu organlarının 
sayısı çoğaldıkça öğrenmenin kalıcılığı da aynı oranda yükselmektedir. Bu durumda yaparak yaşayarak öğrenme en aktif öğrenme yöntemlerindendir (Kırbaş, 2010).

Günümüzde, artık öğrencilere bilgiyi depolamaktan ziyade bilgiye nasıl ulaşacakları ve herhangi bir problem durumunda problemi çözmek için probleme nasıl yaklaşacaklarını öğretmeye yönelik bir eğitim anlayışı içine girilmiştir. Öğrenmeyi kalıcı hale getirebilmek için birçok öğrenme modeli oluşturulmuş, bu modellere uygun yöntem ve teknikler geliştirilmiştir (Çelikkaya, 2008).

Eğitim ve öğretimde, öğretmen dersi uygulayacağı strateji, yöntem ve teknik ile daha kalıcı ve eğlenceli duruma getirebilmektedir (Ergani, 2010). Öğretmenlerin bilgiyi direkt olarak öğrenciye aktarmak yerine, öğrencileri öğrenmeye yönlendirecek şekilde derslerini düzenlemesinin ve bu aşamada farklı strateji, yöntem ve teknikleri kullanmasının bir hayli önemli olduğu söylenebilir. Fakat yapılan araştırmalar, öğretmenlerin öğrencilerinin derse aktif katılımını sağlayacak farklı öğretim strateji, yöntem ve teknikler konusunda yetersiz kaldıklarını göstermektedir (Gönen ve Kocakaya, 2006). Ders sürecinde az sayıda duyu organına hitap edilmesi, öğrenme sürecini zorlaştırmaktadır. $\mathrm{Bu}$ anlamda daha çok duyu organına hitap eden çalışmalar yapılmalıdır. Öğrenme sürecinde materyal kullanım eksikliği öğrenme sürecini zorlaştırmakta ve kavram yanılgılarını artırmaktadır (Çoruhlu vd., 2019a, b, c). Öğrenci kazanımlarına uygun olarak kullanılacak olan materyaller hem öğrenci merkezli öğrenme anlayışını geliştirilebilmekte, hem de yaparak yaşayarak öğrenme ile daha kalıcı hale gelebilmektedir.

$\mathrm{Bu}$ bağamda çalışma haritacılık eğitiminin temel basamaklarından olan 4. seviyedeki ortaöğretim müfredatında çalışma kapsamında uygun görülen dersler özelinde ele alınan müfredat materyalleri ile birlikte incelenmiştir. Bu inceleme de materyallerin varlığı ve yeterliği noktasında sorunlar tespit edilmiştir. Öğretimin daha kalıcı hale gelmesi için materyallerin öğretmen rehberliğinde öğrenciler tarafından geliştirilmediği, bu durumunda öğrencilerin müfredatı kalıcı bir şekilde öğrenememesine sebebiyet verdiği görülmüştür.

\subsection{Problemin Tanımı}

Haritacılık eğitiminin en temel basamağ olan 4.seviyedeki ortaöğretim müfredatında çalışma kapsamında uygun görülen dersler özelinde ele alınan müfredat materyalleri incelendiğinde; materyallerin varlığı ve yeterliği noktasında sorunlar tespit edilmiştir. Öğretimin daha kalıcı hale gelmesi için materyallerin öğretmen rehberliğinde öğrenciler tarafından geliştirilmediği, bu durumunda öğrencilerin müfredatı kalıcı bir şekilde öğrenememesine sebebiyet verdiği görülmüştür. $\mathrm{Bu}$ durum, çalışma özelinde problem tanımı olarak değerlendirilmiştir. 


\section{2. Çalışmanın Amacı}

Problem tanımı olarak ifade edilen soruna ilişkin olarak öğrencilerin ders materyali geliştirmeleri amaçlanmıştır. Bu amaç doğrultusunda; öğrencilerde bilgi eksikliklerini giderme, kalıcı öğrenmenin sağlanması, öğrenci merkezli öğrenme yaklaşımının öğrenci düzeyine uygun olarak aktarılması, yaparak yaşayarak öğrenmenin öğrencinin bilgi durumunu daha kalıcı hale getirilmesi, öğrencilerin bilgiyi sıkılmaksızın eğlenceli bir hale getirerek kendi çabalarıyla öğrenmesi, gerek bireysel öğrenme ile kendini geliştirmesi, gerekse de öğrenci gruplarıyla iletişim halinde bu çalışmaları gerçekleştirmesi, hem iletişim yönünden kendini geliştirmesi hem de grup çalışmasıyla birlikte öğrencinin daha aktif olması ve sosyolojik açıdan da kendini daha iyi ifade etmesi hedeflenmiştir

\section{Yöntem}

$\mathrm{Bu}$ çalışmada vaka çalışması bir yöntem olarak kullanılmıştır. Materyal olarak, giriş bölümünde verilen verinin yanında mevcut durum analizinde haritacılığın eğitim boyutlu analizi yapılacaktır. $\mathrm{Bu}$ bağlamda, mevcut eğitimin eksiklikleri ortaya konulacaktır. Mevcut eğitim öğretimin derslerin öğretim strateji yöntem ve tekniklerine uygun olarak planlanması ve işlenmesi, öğrencilerin bilgi eksiklikleri farklı ölçme ve değerlendirme araçları ile tespit edilmesi (Çoruhlu ve Uzun, 2018), öğrencilerdeki bilgi eksikliklerinin giderilmesi için materyal geliştirilmesi, derslerin işlenmesinde ve materyallerin uygulanmasında öğrenci merkezli yaklaşım üzerine analizler yapılacaktır. Çalışma kapsamında Şekil 1'de hazırlanan işlem adımları izlenmiştir.

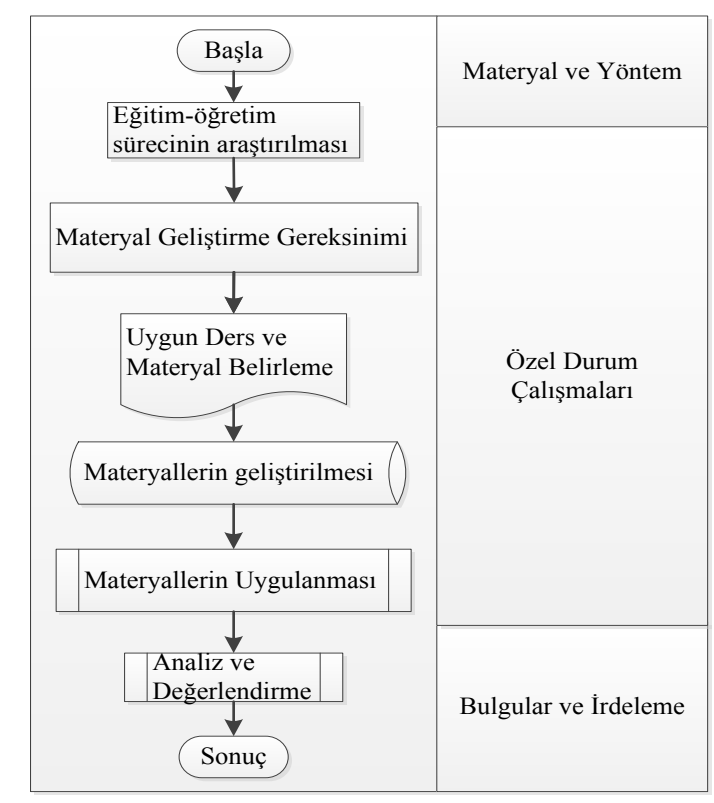

Şekil 1. Metodoloji ve çalışma planı 


\subsection{Haritacılıkta Ĕgitim Analizi}

Haritacılık alanında en alt seviyede eğitim ortaöğretimde verilmektedir. Bu disiplin üniversite eğitimi ile birlikte gerek ulusal ve gerek uluslararası alanda birçok alt bilim dallarına ayrılmaktadır. Her bir bilim dalı haritacılık faaliyet alanının farklı konuları ile ilgilenmektedir (Karaağaç, 2019). Bu disiplin, uluslararası seviyede geomatics engineering, surveying engineering, geodesy and photogrametry engineering gibi isimlerle bilinmektedir. Türkiye'de ise; Türkçe olarak "Harita Mühendisliği”, “Jeodezi ve Fotogrametri Mühendisliği”, “Geomatik Mühendisliği” olmak üzere üç farklı isimle anılmaktadır (Yildirim ve Baser, 2020).

Son yıllarda uydu teknolojilerinde yaşanan hızlı gelişmeler, başta jeodezik altyapı olmak üzere, harita üretim faaliyetlerini hızlandırmıştır. Konum belirleme çalışmaları GNSS teknolojisi ve teknikleri ile daha hızlı ve yüksek doğrulukta yapılabilir hale gelmiştir. Ayrıca veri toplama yeteneklerini geliştirmek için fotogrametri ve uzaktan algılamada daha sofistike kameralar ve sensörler kullanılmaktadır (Gong vd., 2017). Görüntü yorumlama ve bilgi çıkarma için yeni teoriler ve metodolojiler uygulanmaktadır. Bulut bilişim, büyük ölçekli dizi veritabanları ve nesnelerin interneti gibi yeni gelişen teknolojiler, mekansal bilgi biliminin erişimini genişleterek, daha önce çeşitli bilimsel etki alanlarını aşan yanıtlanamayan soruları yanıtlamamıza izin vermektedir (Yue vd., 2016). Diğer taraftan harita mühendisliği disiplini, arazi yönetimi uygulamaları olarak bilinen kadastro, imar, kentsel ve kırsal alan düzenlenmesi faaliyetleri de gerçekleştirmektedir. Türkiye'de son yıllarda hızlı bir şekilde kentsel dönüşüm uygulamaları ve taşınmaz değerleme çalışmaları da yürütülmektedir. $\mathrm{Bu}$ çalışmalarda uygun yer seçimi için yapılan konumsal analizler sıkça kullanılmaktadır. Kültür ve tabiat varlıklarının korunması, vakıf arazilerinin yönetilmesi gibi birçok alan haritacılık ile ilişkilidir.

Türkiye'de harita alanında eğitim veren birçok eğitim kurumu bulunmaktadır. Haritacılık eğitimi mesleki seviye açısından 4. seviyeden başlamaktadır. Bu seviyede mesleki/teknik liselerde dört yıl süreyle eğitim verilmektedir. Ardından üniversitelerin meslek yüksekokulları (iki yıl) ve mühendislik fakültelerinde (dört yıl) eğitimler verilmektedir. Bunların dışında mesleki anlamda derinlemesine bilgi ve araştırmalar için enstitülerin bünyesinde yüksek lisans ve doktora programları mevcuttur. Ayrıca bunlara ilaveten yaşam boyu öğrenme de eğitimin sürdürülebilir olması için önemi bir parçadır.

\subsubsection{Ortaöğretimde Harita Disiplini Eğitimi}

Harita tapu kadastro alanı altında yer alan haritacılık, kadastroculuk ve tapuculuk dalların yeterliklerini kazandırmaya yönelik eğitim ve öğretim verilen alandır. Harita tapu kadastro alanı 
altında yer alan mesleklerde sektörün ihtiyaçları, bilimsel ve teknolojik gelişmeler konusunda gerekli olan mesleki yeterlikleri kazanmış nitelikli meslek elemanları yetiştirmek ve bu elemanları sektöre kazandırmak amaçlanmaktadır. Haritacılık dalı, haritacının sahip olması gereken arazi ölçümü, harita çizimi ve harita hesaplamaları yapma yeterliklerini kazandırmaya yönelik eğitim ve öğretimin verildiği daldır. Tapuculuk dalı, tapucunun sahip olması gereken tapu siciline konu olan tüm işlemleri yapma yeterliklerini kazandırmaya yönelik eğitim ve öğretim verilen daldır. Kadastroculuk dalı, kadastrocunun sahip olması gereken gayrimenkullerin sınırlarını arazi ve harita üzerinde belirleme, hukuki durumlarını ve üzerindeki hak ve yükümlülükleri belirleme ve kadastroyu yenileme yeterliklerini kazandırmaya yönelik eğitim ve öğretim verilen daldır (URL-1, 2019). Ülkemizde Mesleki ve Teknik Anadolu Liseleri (MTAL) içinde Harita, Tapu ve Kadastro programları mevcuttur. Öğrenim süreleri 4 yıldır. Bu liselerden mezun olanlar 'Harita Teknisyeni' unvanı almaktadır

\subsection{2. Ön lisans Harita Disiplini Eğitimi}

Üniversiteler bünyesinde Harita ve Kadastro Meslek Yüksekokulları iki yıl süreli ön lisans eğitimi vermektedir. Meslek yüksekokulundan mezun olan öğrenciler 'Harita Teknikeri' unvanını almaktadırlar. Ülkemizde ara eleman ihtiyacı ön lisans mezunu harita teknikerleri ile karşılanmaktadır. Birçok mühendislik projelerinin harita ve harita bilgilerini oluşturan ve bunları yerine uygulayan harita teknikerliğinin kentsel ve kırsal alan düzenlemeleri başta olmak üzere tüm haritacılık faaliyetlerinde önemli görevleri vardır. Meslek yüksekokulları, her devirde çağdaş teknolojileri kullanarak kamunun ve özel sektörün ihtiyaç duyduğu arazi ve endüstri ölçmeleri, taşınmaz değerleme ve konum belirleme, coğrafi ve kent bilgi sistemi kurma ve sorgulama, konum bilgilerini yerine uygulama, taşınmaz mal mülkiyeti ile ilgili hukuki ve teknik bilgileri değerlendirme vb. konularda kendini geliştirmiş, teknik elemanların yetiştirilmesini hedefler (Boztoprak vd., 2017).

\subsubsection{Lisans ve Lisansüstü Harita Disiplininin Eğitimi}

Türkiye' de bayındırlık ve imar faaliyetleri ile teknik hizmet ihtiyacının artması sebebiyle Milli Eğitim Bakanlığı'nın 07 Haziran 1949 tarihli kararıyla Yıldız Teknik Üniversitesi’nde Harita ve Kadastro Mühendisliği Bölümü kurulmuştur. Türkiye'de bu alanda mühendis yetiştiren ilk bölüm olarak 1949 yılında eğitim-öğretime başlamıştır. Daha sonra yıllar içinde İstanbul Teknik Üniversitesi ve Karadeniz Teknik Üniversitesi gibi köklü üniversitelerde de Harita ve Kadastro Mühendisliği Bölümü kurulmuştur. Bölümün adı önceden, Jeodezi ve Fotogrametri Mühendisliği olarak kullanılırken günümüzde bu isim Harita Mühendisliği veya Geomatik Mühendisliği olarak 
kullanılmaktadır. Ülkemizde, Harita Mühendisliği veya Geomatik Mühendisliğinin bazı bölümlerinde yüksek lisans ve doktora eğitimi de verilmektedir.

\subsubsection{Harita Tapu Kadastro Alanı Meslek Dersleri}

Öğrencilere, çerçeve öğretim programı ile alan ve dallar ile ilgili temel bilgi ve becerileri kazandırma dışında, öğrencinin teknolojiye, değişime uyum sağlayabilen, çevresindeki insanlarla iletişim becerisi yüksek, hedeflerini belirleyip bunlara ulaşmak için girişimlerde bulunabilen, yaratıcı, her türlü eleştiriye açık ve mesleki bilgiye sahip bireyler yetiştirilmesi hedeflenmiştir. Harita tapu kadastro alanı dört yıl olarak belirlenmiş ve program Anadolu meslek lisesi ve Anadolu teknik lisesi olmak üzere iki okul türünde okutulmaktadır. Anadolu teknik liselerine giriş, liselere giriş sınavlarıyla belirlenmektedir. Programın temel yapısını dokuzuncu sınıfta ortak dersler, onuncu sinıfta ortak dersler ile alan ortak dersleri, 11. ve 12. sınıflarda ortak dersler ile öğrencinin tercihte bulunduğu dallara ilişkin ders modülleri oluşturmaktadır. Bu kapsamda öğrenme süresi 40 saat olarak planlanmıştır. Tablo 1'de Alan/dal dersleri içinde (*) ile belirtilen dersler, öğrencilerin geçmekle yükümlü oldukları zorunlu derslerdir. Bu dersler Millî Eğitim Bakanlığı Ortaöğretim Kurumları Sınıf Geçme ve Sınav Yönetmeliği’nin 33. maddesi uyarınca yılsonu başarı ortalaması ile başarılı sayılmayacak derslerdir. Yani öğrencinin bu dersleri geçebilmesi için yılsonu başarı ortalamasının 50 ve üzerinde olması gerekir. Öğrencinin bu koşulu sağlayamaması durumunda bir sonraki eğitim öğretim yılı içerisinde yapılacak sorumluluk sınavlarına girmesi gerekmektedir. Sorumluluk sınavları her sene eğitim öğretim yılının ilk haftası ve ikinci dönemin ilk haftasında olmak üzere yapılmaktadır. Harita tapu kadastro alanında yer alan tüm dallar için geçilmesi zorunlu olan dersler Tablo 1'de verilmiştir (URL-1, 2019).

Tablo 1. Harita Tapu Kadastro alanı başarılması zorunlu dersler (URL-1, 2019)

\begin{tabular}{|l|c|c|}
\hline \multirow{2}{*}{ Alana ait alt dallar } & \multicolumn{2}{|c|}{ Geçmesi Zorunlu Dersler } \\
\cline { 2 - 3 } & Meslek Lisesi ve Anadolu Meslek Lisesi & Teknik Lise ve Anadolu Teknik Lisesi \\
\hline \multirow{3}{*}{ Harita } & $*$ Temel Mesleki Uygulamalar & $*$ Temel Mesleki Uygulamalar \\
\cline { 2 - 3 } & $*$ Arazi Ölçme ve Hesapları & $*$ Arazi Ölçme ve Hesapları \\
\cline { 2 - 3 } & $*$ İşletmelerde Beceri Eğitimi & $*$ İmar Uygulamaları \\
\hline \multirow{3}{*}{ Kadastro } & $*$ Temel Mesleki Uygulamalar & $*$ Temel Mesleki Uygulamalar \\
\cline { 2 - 3 } & $*$ Kadastro Hukuksal İşlemleri & $*$ Kadastro Hukuksal İşlemleri \\
\cline { 2 - 3 } Tapu & $*$ İşletmelerde Beceri Eğitimi & $*$ Kadastral Kontroller \\
\cline { 2 - 3 } & $*$ Temel Mesleki Uygulamalar & $*$ Temel Mesleki Uygulamalar \\
\cline { 2 - 3 } & $*$ Akitli-Akitsiz İşlemler & $*$ Resmî Yazișişmalı İşşlemlemler \\
\hline
\end{tabular}




\subsubsection{Harita Disiplini Eğitiminin Karşılaştırılması}

Lisans seviyesindeki Harita Mühendisliği ile ortaöğretim düzeyindeki harita tapu kadastro alanını karşılaştırdığımızda benzer dersler ve benzer konular göze çarpmaktadır. Harita Mühendisliği bölümünde yer alan Ölçme Bilgisi dersinin birçok konu kazanımı, ortaöğretim harita tapu kadastro alanında Arazi Ölçme ve Hesapları dersi kapsamında aynen verilmektedir. Yine Mühendislik Ölçmeleri, Jeodezik Ölçmeler, Kadastro Bilgisi, Yükseklik Ölçmeleri, GNSS (Global Navigation Satellite System-Küresel Konumsal Uydu Sistemi) Ölçmeleri, Kentsel Alan Düzenlemesi, Kırsal Alan Düzenlemesi gibi mühendislik dersleri, ortaöğretim alanında Harita Hesapları, Temel Mesleki Uygulamalar, İmar Uygulamaları, Yol Uygulamaları, Özel Ölçmeler gibi derslerle aynı ya da benzer konu kazanımlarını içermektedir. Bu kazanımlara yönelik olarak öğretmenler tarafından öğrencilere yaptırılan, ölçümler, çizimler ve diğer uygulamalar da benzerlik göstermekte hatta zaman zaman birebir olarak bu kazanımların örtüştüğü görülmektedir (URL-1, 2019).

\section{2. Ĕgitim Öğretim Stratejileri}

Strateji, öğretimin psikolojik durumlarının da dikkate alındığı, dersin önceden belirlenen hedeflerine ulaşmayı amaçlayan, öğretim sürecine temel olarak yön veren faaliyetler şeklinde tanımlanabilir. Strateji, yöntem ve tekniği içine alır. Sunuş, buluş, araştırma inceleme, kubaşık (işbirlikçi) ve tam öğretim stratejisi olmak üzere beşe ayrılır (Taşpınar ve Atıc1, 2002).

Öğretim yöntemleri öğrenmeyi sağlamak için yapılan uygulamalardır. Uygulamaların başarısı öğretmenlerin yöntemleri kullanma becerisine bağlıdır (Çiçek, 2012). Tümevarım ve tümdengelim, tanımlar yardımıyla öğretim, analizle öğretim, sözlü anlatım, drama, tartışma, yazılı anlatım, problem çözme, bilgisayar destekli eğitim, örnek olay gibi çeşitleri vardır.

Öğrenmeyi kolaylaştıracak bu öğretim teknikleri etkinlikleri belirleme, öğrencilere rehber olma, herhangi bir konuda öğrencilere farklı yollarla bilgiyi aşılamak amacıyla kullanılır. Altı şapkalı düşünce, altı ayakkabılı uygulama, gösteri, soru cevap, rol oynama, drama, benzetim, analoji, mikro öğretim, eğitsel oyun, deney, istasyon, konuşma halkası, balık kılçığı, bilişsel çıraklık, beyin firtınası, gösterip yaptırma, gezi, gözlem, görüşme, ödev, sergi gibi çeşitleri vardır (Sönmez, 2009).

Öğretim materyalleri, ders araç ve gereçlerinden faydalanılarak yapılan ders sunum içerikleridir (Yanpar, vd., 2006). Önemli olan araçları derste öğrencilerin kazanımlarını gerçekleştirmek üzere yaratıcı bir biçimde sentezlemek, bu sentezleri materyal hazırlama ve tasarım ilkelerini kullanarak geliştirmektir. Eğitimin niteliğini arttırmada öğretim materyalleri, çok önemlidir (Yanpar, vd., 2006). 
Teknoloji ne kadar gelişirse gelişsin insan eliyle üretilen materyaller bireylerin öğrenme yaşantılarının kalıcılığında etkili bir rol oynamaktadır (Yanpar, 2009).

Öğretim aracı eğitim ortamında kullanılırken, materyal ise öğretim ortamında kullanılmak üzere öğretmen tarafından hazırlanan malzeme ya da araçtır. Bir malzemenin öğretim ortamında etkili bir araç olarak kullanılması için öncelikle amaca uygun olarak hazırlanmış olması gerekir.

Öğrenilenlerin yaşantı konisi içinde basitten karmaşığa somuttan soyuta çok sayıda duyu organı ile edinilenden az sayıda duyu organıyla edinilene doğru bir süreç içinde edinildiği görülmektedir. Duyu organı sayısının fazlalığı öğrenme işlemini o kadar etkili kılmaktadır (Çilenti, 1991).

Materyal ile öğrenmenin faydalarından biride dikkat eksikliğini minimize etmesidir (Çelik ve Şahin, 2013). Materyaller, öğrencileri pasif durumdan aktif duruma geçirmeleri nedeniyle dikkat üzerinde önemli bir etkiye sahiptir Materyal, bir eğitim aracı olup, eğitimin bütün dallarında öğretim için hem metot hem de araçtır. Materyalle eğitim ile öğrenilenler daha iyi hafizada kalır, mukayeseli düşünme, karar verme ustalığı gelişir ve davranışları olumlu yönde etkiler (Çelik ve Şahin, 2013).

Kendi ders materyallerini kendi hazırlayan öğrencinin, üretilecek materyal hakkında, materyalin ait olduğu ders ve konu hakkında bilgi sahibi olacağından bilişsel; materyali üretme aşamasında devinişsel; ortaya özgün ve ona ait bir ürün koyduğu zaman da duyuşsal kazanımları en üst seviyede olacaktır (Demirel, 2007).

Öğretim materyali amaçlı ve planlı olarak hazırlanmalı ve kullanılmalıdır. Hazırlanacak olan öğretim materyali dersin hedef ve davranışlarına, öğrenci grubunun özelliklerine ve hazır bulunuşluk seviyelerine uygun bir halde olmalıdır. Materyalde kullanılacak nesneler öğrenci yapısına uygun, öğrenci açısından rahatça anlaşılabilecek nitelikte olmalıdır. Materyal içerik açısından basit, sade ve anlaşılır olmalıdır. Materyal içindeki detaylar birbirleriyle bütünlük halinde olmalıdır. Yazılı metinler ve görsel işitsel öğeler, öğrencinin gelişim ve öğrenim düzeylerine uygun olmalıdır. Öğretim materyali öğrenciyi öğrenme etkinliğine katacak, öğrencinin derse katılımını teşvik edecek özelliklerde olmalıdır. Öğretim materyali her öğrencinin kullanımına açık olmalıdır. Hazırlanacak olan materyali, öğrenci tek başına da kullanabilmelidir. Materyal dayanıklı olmalı, tekrar tekrar kullanılmaya yönelik sağlam bir şekilde tasarlanmalıdır. Gerektiğinde günümüz şartlarına uygun, geliştirilebilir ve teknolojik gelişmelere bağlı olarak güncelleştirilebilir olmalıdır (URL-2, 2019).

\subsection{Materyal Hazırlama İlkeleri}

Öğretim materyalleri hazırlarken öğrenmede belirtilen hedeflere ulaşmada en hızlı ve en etkin öğrenmeyi sağlayacak detayların seçimi ve düzenlenmesi gerekmektedir. Materyalde kullanılan her türlü unsur bir bütünlük içinde olmalıdır. Objeleri seçerken renkler dâhil en küçük detay dahi dikkate 
alınmalıdır (Vural, 2004). Materyaller öğrencinin konuyu öğrenmesine ve yapılan öğretime verimli bir biçimde katkıda bulunduğu ölçüde etkilidir, anlamlıdır (URL-2, 2019).

Görsel nesneler sözlü mesaj iletmek için kullanılabilir. Renkli bir fotoğraf, anlatılmak istenen nesnenin gerçekliğini yüksek bir düzeyde yansıtabilir. İyi bir şekilde tasarlanmış materyal ile dil ve kültür sınırları aşılarak farklı kültürlerde ki insanlarla iletişim kurulabilir. Fotoğraflar, resimler, çizimler, sözcükler; somuttan soyuta doğru devamlılık gösterir. Öğretim materyalleri kullanırken, öğretmen planında hangi araç ve gereçleri, hangi konu ve kazanım için materyali hangi zaman diliminde kullanacağını belirtmeli ve zamanı gelince bu araç gereci kullanmalıdır. Alanla ilgili davranışlar öğrencilere kazandırılırken her bir öğrenciye öğretim materyalleri sağlanmalıdır. Öğretim materyalleri kullanımı kolay olmalı, öğrenci en az çaba ile en hızlı zamanda materyal ile öğrenilmesi istenilen bilgiye ulaşmalıdır (URL-2, 2019).

\section{Bulgular}

Çalışma, Giresun Tirebolu Şehit İsmail Kefal Mesleki ve Teknik Anadolu Lisesi harita tapu kadastro bölümünde gerçekleştirilmiştir. Bu bölümdeki, onuncu sınıf Harita Hesapları ve Temel Mesleki Uygulamalar dersleri, 11. sınıf, Arazi Ölçme ve Hesapları ve Harita Çizimi dersleri, 12. sınıf, Yol Uygulamaları, İmar Uygulamaları, Özel Ölçmeler ve Bilgisayarlı Harita Çizimi dersleri için materyal geliştirilmesi planlanmıştır. Zira bu derslerin bazı bölümleri lisans seviyesinde harita/geomatik mühendisliği bölümünde okutulmaktadır. Bunlar; Ölçme Bilgisi, Yükseklik Ölçmeleri, Jeodezik Ölçmeler, Mühendislik Ölçmeleri, GNSS Ölçmeleri, Arazi Uygulaması, Bilgisayar Destekli Harita dersleridir. Materyal geliştirilmesi planlanan ortaöğretim dersleri için sınav analizleri sonucu ortaya çıkan kavram yanılgılarını içeren konuların ele alınması hedeflenmiştir. Böylece benzer konular lisans müfredatında da ele alınarak benzer yaklaşımlarla materyaller hem uygulanabilir ve hem de geliştirilebileceği düşünülmüş̧ür.

\subsection{Bilgi Eksikliği Olan Konuların Sınav Analizi ile Belirlenmesi}

Çalışma kapsamında Tirebolu Şehit İsmail Kefal Mesleki ve Teknik Anadolu Lisesi harita tapu kadastro alanı harita hesapları, temel mesleki uygulamalar, arazi ölçme ve hesapları, harita çizimi, yol uygulamaları, imar uygulamaları, özel ölçmeler ve bilgisayarlı harita çizimi derslerine ait sınav analizi ve başarı değerlendirmesi yapılmıştır.

Çalışma kapsamında onucu sınıf Harita Hesapları ve Temel Mesleki Uygulamalar dersleri, 11. sınıf, Arazi Ölçme ve Hesapları ve Harita Çizimi dersleri, 12. sınıf, Yol Uygulamaları, İmar 
Uygulamaları, Özel Ölçmeler ve Bilgisayarlı Harita Çizimi dersleri kapsamında sınav analizi ve değerlendirmeleri yapılmıştır. Bu değerlendirmeler harita tapu kadastro alanında okuyan tüm sınıf düzeyleri ve öğrencileri dikkate alınarak gerçekleştirilmiştir. Bu kapsamda;

onuncu sınıf öğrenci sayısı 34 kişi,

11. sınıf öğrenci sayısı 18 kişi,

12. sınıf öğrenci sayısı 22 kişi olmak üzere toplamda 74 öğrenci bu çalışmalara aktif bir şekilde dâhil edilmiştir.

Yapılan çalışma, soru analizi ve sınav başarı değerlendirmesi başlıklı olmak üzere analiz edilmiştir. Analiz dâhilinde, sınav sorularının ilgili olduğu konular, sorulara göre başarı yüzdeleri ve bunların grafik analizleri, sorulan tüm sorular için öğrencilerin bireysel anlamda her sorudan aldıkları puanlar ve alınan puanların ortalaması, sınıfın başarı yüzdesi, sınava katılan öğrenciler ve bu öğrencilerin sınavdan aldıkları puanlar ve başarı yüzdesinin düşük olduğu (\%50’nin altında) konular belirlenmiştir. Bu bağlamda Bilgisayarlı harita çizimi dersi sınavında sorulan soruların analizinde (şekil 2); eş yükselti eğrileri konusuna ilişkin materyal çalışması amacıyla yöneltilen birinci soru analiz edilmiştir. $\mathrm{Bu}$ analize göre bu sorudan öğrencilerin başarı ortalamasının \% 47 olduğu görülmektedir. Aynı şekilde diğer dersler içinde analizler gerçekleştirilmiştir.

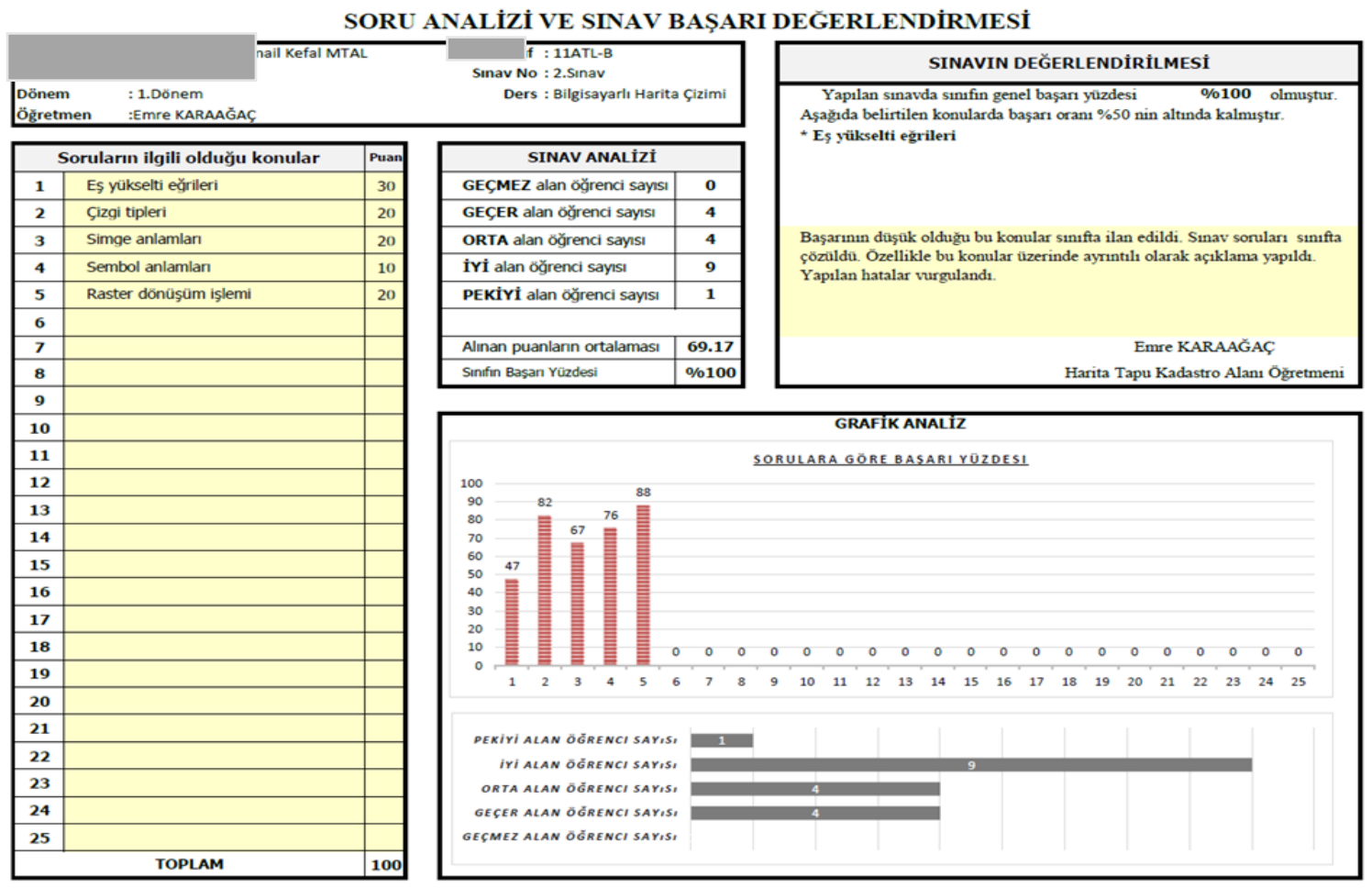

Şekil 2. Bilgisayarlı harita çizimi dersi sınav analizi

Şekil 2’ye benzer şekilde, Harita Hesapları dersi sınav analizinde; uzunluk, alan, hacim birimleri konusuna ilişkin materyal çalışması amacıyla yöneltilen sorudan öğrencilerin başarı 
ortalamasının \% 36 olduğu görülmektedir. Derece açı birimi sistemi konusuna ilişkin materyal çalışması amacıyla yöneltilen sorudan öğrencilerin başarı ortalamasının \% 28 olduğu görülmektedir. Temel Mesleki Uygulamalar dersi sınav analizinde; elektronik uzaklıkölçer parçaları ve işlevleri materyal çalışması amacıyla yöneltilen soru ile ölçek konulu materyal çalışması amacıyla yöneltilen soru analiz edilmiştir. Bu analizlere göre öğrencilerin başarı ortalamasının sırasıyla \% 35 ve \% 49 olduğu görülmektedir. Arazi Ölçme ve Hesapları dersi sınav analizinde; detay ölçmeleri konulu materyal çalışması amacıyla yöneltilen soru analiz edilmiştir. Bu analize göre sorudan öğrencilerin başarı ortalamasının \% 23 olduğu görülmektedir. Elektronik uzaklıkölçer parçaları ve işlevleri konusu ile ilgili materyal çalışması amacıyla yöneltilen sorudan öğrencilerin başarı ortalamasının \% 39 olduğu görülmektedir. Nirengi nokta tesisi - pilye konusu ile ilgili materyal çalışması amacıyla yöneltilen sorudan öğrencilerin başarı ortalamasının \% 27 olduğu görülmektedir. GPS sistemi ve çalışma prensibi konusu ile ilgili materyal çalışması amacıyla yöneltilen sorudan öğrencilerin başarı ortalamasının \% 12 olduğu görülmektedir. Yol Uygulamaları dersi sınav analizinde; dever konusuna ilişkin materyal çalışması amacıyla yöneltilen soru analiz edilmiştir. Bu analize göre bu sorudan öğrencilerin başarı ortalamasının \% 45 olduğu görülmektedir. Bu başarı durumlarının materyal geliştirildikten sonra ne oranda değiştiği ödev notu başarı oranı ile elde edilerek materyalin etkinliği bulgular ve irdeleme bölümünde ele alınmıştır.

\subsection{Bilgi Eksikliği Giderme Amaçlı Oluşturulacak Materyal Geliştirme Kapsamında Seçilen Dersler ve Kazanımlar}

Kavram yanılgısını giderme amaçlı çalışma kapsamında oluşturulacak materyal geliştirme için seçilen dersler ve kazanımları aşağıdaki tabloda gösterilmiştir. Bu tablo sınav analizi ve başarı değerlendirmeleri kapsamında belirlenen kavram yanılgılarını gidermek amacıyla hazırlanmıştır. Kavram yanılgısı olan konuların, üniversitede yer alan hangi dersin karşılığına ve konusuna denk geldiği Tablo 2'de gösterilmiştir.

Tablo 2. Bilgi eksikliği olan ders, konu ve kazanımlar

\begin{tabular}{|c|c|c|c|}
\hline $\begin{array}{c}\text { Lisede Okutulan } \\
\text { Ders Adı }\end{array}$ & Kavram Yanılgısı Olan Konu & $\begin{array}{c}\text { Üniversitede Okutulan } \\
\text { Ortak Ders Adı }\end{array}$ & $\begin{array}{c}\text { Üniversitede Okutulan Ders } \\
\text { Kazanımı }\end{array}$ \\
\hline \multirow{3}{*}{$\begin{array}{c}\text { Arazi Ölçme ve } \\
\text { Hesapları }\end{array}$} & Detay Ölçmeleri & Arazi Uygulaması & Çeşitli koordinat hesaplamaları \\
\cline { 2 - 4 } & GPS sistemi & GNSS Ölçmeleri & Konum belirleme sistemleri - GPS \\
\cline { 2 - 4 } & $\begin{array}{c}\text { Nivelman hesabı ve nokta } \\
\text { tesisi-bronz }\end{array}$ & Jeodezik Ölçmeler & $\begin{array}{c}\text { C3 derece noktaların arazide yerlerinin } \\
\text { seçimi ve oluşturulması }\end{array}$ \\
\cline { 2 - 4 } & \multirow{2}{*}{$\begin{array}{c}\text { Yükseklik Ölçmeleri } \\
\end{array}$} & & Geometrik yükseklik tayini \\
\hline
\end{tabular}




\begin{tabular}{|c|c|c|c|}
\hline Harita Çizimi & Eş Yükselti Eğrileri & Yükseklik Ölçmeleri & $\begin{array}{c}\text { Eş yükselti eğrilerinin özellikleri ve } \\
\text { çizimi }\end{array}$ \\
\hline Harita Hesapları & $\begin{array}{c}\text { Birimler arasındaki dönüşümler, } \\
\text { açı ve dönüşümleri }\end{array}$ & Ölçme Bilgisi & Uzunluk, alan, açı ve yay birimleri \\
\hline \multirow{2}{*}{$\begin{array}{c}\text { Temel Mesleki } \\
\text { Uygulamalar }\end{array}$} & $\begin{array}{c}\text { Elektronik alet, parçaları ve } \\
\text { işlevleri }\end{array}$ & Ölçme Bilgisi & $\begin{array}{c}\text { Elektronik uzaklı̈ölçer ve ölçme } \\
\text { prensipleri }\end{array}$ \\
\cline { 2 - 4 } & Ölçek & Ölçme Bilgisi & Harita ve Ölçek \\
\cline { 2 - 4 } & Harita Çizim Özel İşaretleri & Arazi Uygulaması & Çizim İşleri \\
\hline
\end{tabular}

\subsection{Bilgi Eksikliği Gidermek Amaçlı Geliştirilen Materyal Çalışmaları}

Kavram yanılgılarını gidermek amaçlı çeşitli materyaller hazırlanmıştır. Bunlardan bazıları aşağıda Şekil 3, 4 ve 5'de gösterilmiştir. Şekil 3'te yer alan eş yükseklik eğrileri ve bunların yükseltileriyle bağlı olarak değişen renklerin gösterimi yapılmıştır. Bu çalışmada iki boyutta çizilen eş yükseklik eğrilerinin, üç boyutlu olarak ne anlam ifade ettiği, yükselti basamakları, arazinin topoğrafik durumunun yorumlanması, yükseğe çıkıldıkça renklendirme yöntemiyle hangi yükselti basamağının hangi renkte olması gerektiğini öğrencilere aktarmak ve bu konulardaki kavram yanılgılarını gidermek amaçlanmıştır. Materyali oluşturmada; maliyeti az, kullanışlılığı yüksek ve öğrencide kalıcı izli davranış değişikliği oluşturabilecek şekilde materyal kullanılmaya özen gösterilmiş ve öğrenciler bu ilkeler göz önünde tutularak yönlendirilmiştir. Materyalleri oluştururken; köpük, sulu boya, çöp şiş, alçı, yapıştırıcı, mukavva ve kâğıt kullanılmıştır.
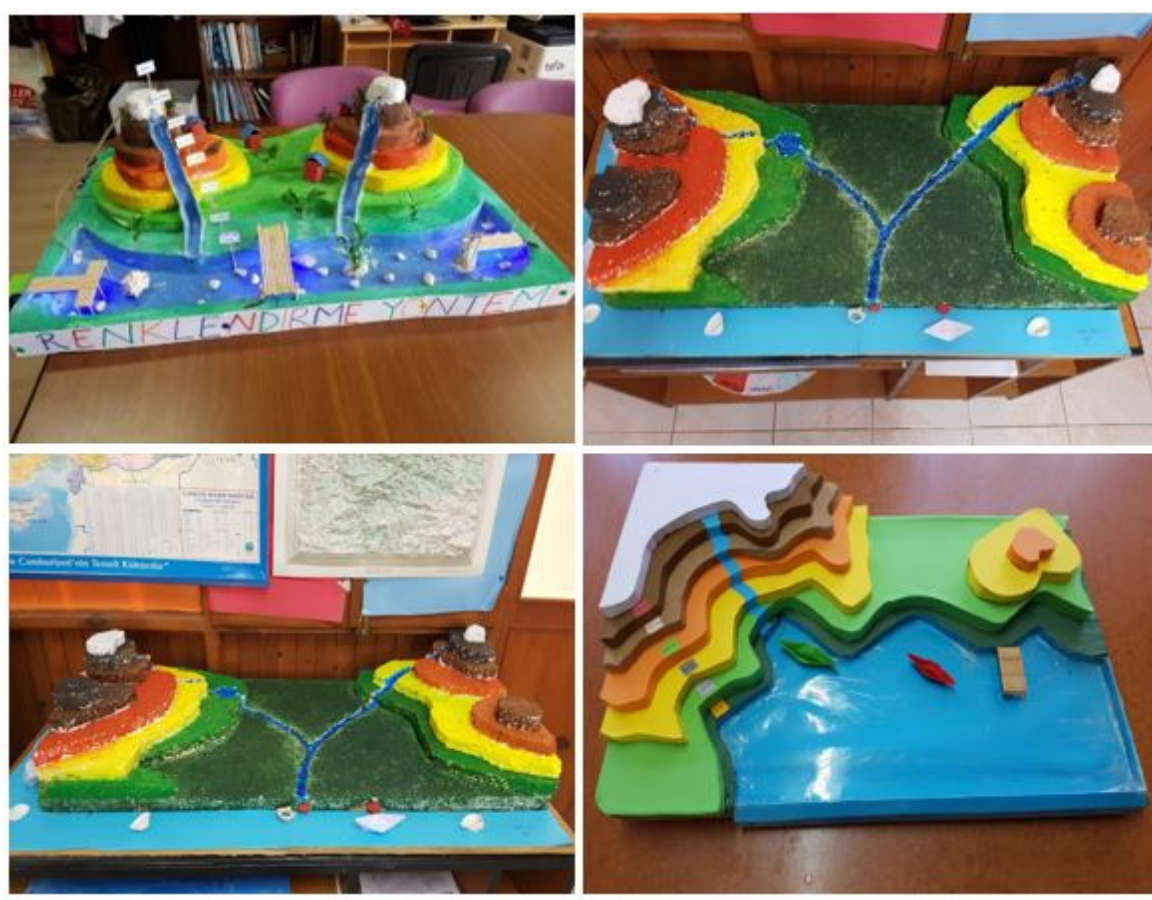

Şekil 3. Eş yükseklik eğrileri - Renklendirme yöntemi materyal çalışması 
Şekil 4'deki detay ölçmeleri ve harita çizim özel işaretleri materyal çalışmasında ilk olarak birçok arazi detayını içeren üç boyutlu maket tasarlanmıştır. Bu detay noktaları; cami, okul, bina, sokak lambası, elektrik direği, telefon direği, spor sahası, rögar kapağı, yol, köprü, toplu mezarlık, ağaçlık alan, inşaat halinde bina, sera ve çeşmedir. Üç boyutlu olarak oluşturulan bu materyal üzerinde aynı zamanda detay ölçmelerinin nasıl yapılması gerektiği rahat bir şekilde anlatılabilmektedir. Materyalde oluşturulan detayların, bir hâlihazır haritada nasıl gösterildiği, hangi sembollerin kullanılması gerektiği de diğer bir materyalde gösterilmiştir. Böylece öğrenci her bir arazi detayına ait üç boyutlu nesneyi görecek ve bu nesnenin haritada nasıl gösterilmesi/çizilmesi gerektiğini de bir alttaki materyalde eş zamanlı olarak tespit edebilecektir. Böylece öğrencide üç boyuttan, iki boyuta geçiş mantığı oluşturulmuş olacak ve bu gösterim şekilleri akılda kalacak biçimde öğrencilerde bilinç oluşturacaktır. Son materyalde de öğrencinin konuyu tekrar etmesi ve öğrendiklerini pekiştirmesi amacıyla bir oyun materyali hazırlanmıştır. Hazırlanan materyal üzerine arazi detaylarına ait fotoğraflar yapıştırılmış ve bu detayların harita çizimindeki karşılıkları da renkli kâğıtlara çizilerek karışık olarak oluşturulmuştur. Bu çizimlerin hepsine 1'den başlayarak numara verilmiştir. Öğrenci hangi fotoğrafın haritada hangi sembolle gösterileceğini bularak, o numaralı kâğıdı harita iğnesi ile ilgili fotoğrafın altına iğneleyecektir. Böylece hem eğlenceli hem öğreten hem de birçok duyu organına hitap eden, öğrenmeyi kalıcı hale getiren, yaparak yaşayarak öğrenme oluşturulacaktır. Bu materyallerde sadece belli bir ders saatine değil, tüm yıllar için kullanılabilir ve geliştirilebilir olarak tasarlanmıştır. Yapılan çizim özel işaretleri çöp şiş, kürdan, yapıştırıcı gibi malzemelerden oluşturularak, öğrenciye yaparak yaşayarak öğrenme sağlanmış ve bilginin daha kalıcı hale getirilmesi sağlanmıştır.

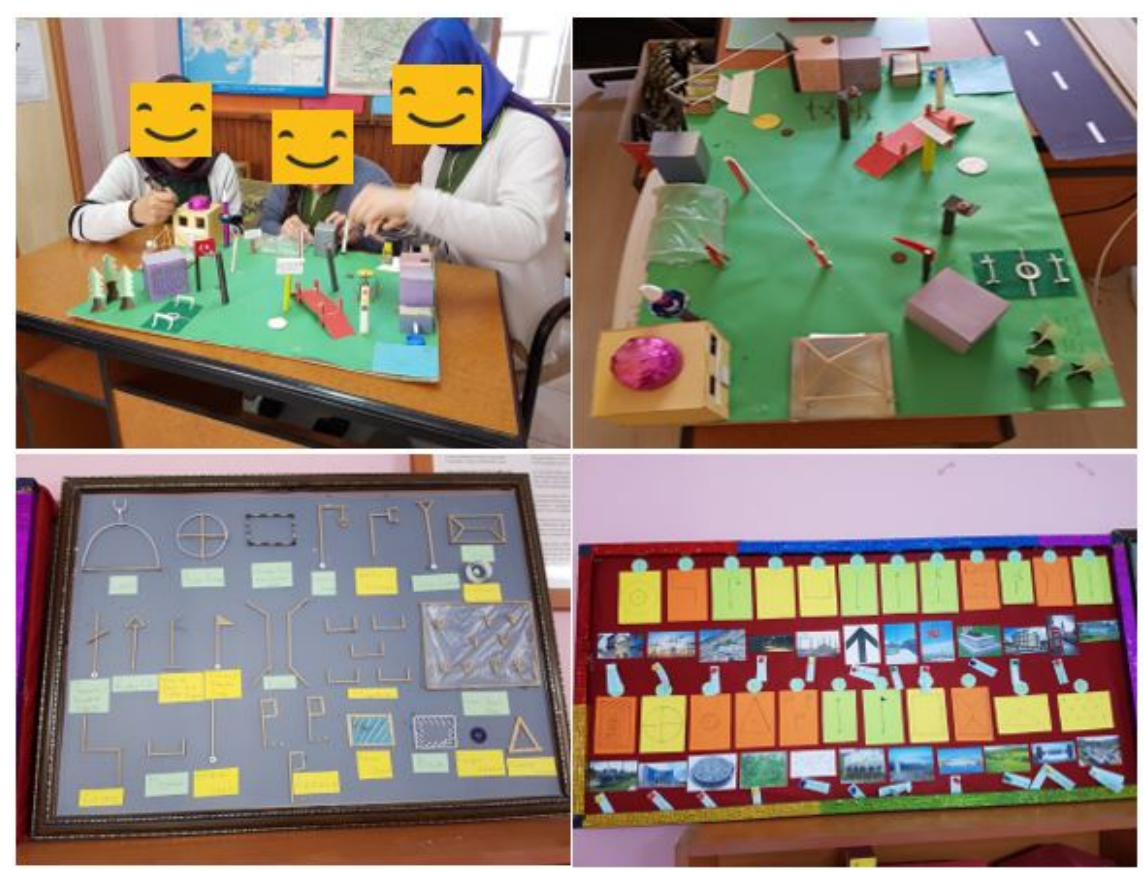

Şekil 4. Detay ölçmeleri ve harita çizim özel işaretleri materyal çalışması 
Şekil 5'de GPS sistemi materyal çalışması gözükmektedir. Materyal yapımında plastik bir top Dünya'yı anımsatacak şekilde tasarlanmış ve üzerine tutkal ile kâğıtlar yapıştırılarak boyanmıştır. GPS sisteminin yörünge sayısı 6 olduğu için Dünya etrafına gelecek şekilde altı tane demir teli kullanılarak köpüğe sabitlenmiştir. Her bit yörünge düzlemi üzerine dört adet GPS uydu tasarımı çöp şiş ve oyun hamuru kullanılarak yapılmış ve toplam da sistemdeki 24 uydu yörüngeye sabitlenmiştir. Ayrıca kullanıcı bölümü amaçlı sabit GPS ve gezici GPS maketleri de yeryüzündeki detaylarını gösterecek olan maket üzerine hazırlanmıştır. Arazi yüzeyindeki detayları oluşturulan maket, hem sistemin nasıl ölçüm yaptığını anlatmada, hem de sinyali kesici durumları materyal üzerinde göstermede kullanılabilecektir. Bu çalışma kapsamında; köpük, demir teli, çöp şiş, oyun hamuru, mukavva, yapıştırıcı, plastik top, ip, renkli kum, sulu boya ve tutkal kullanılmıştır.

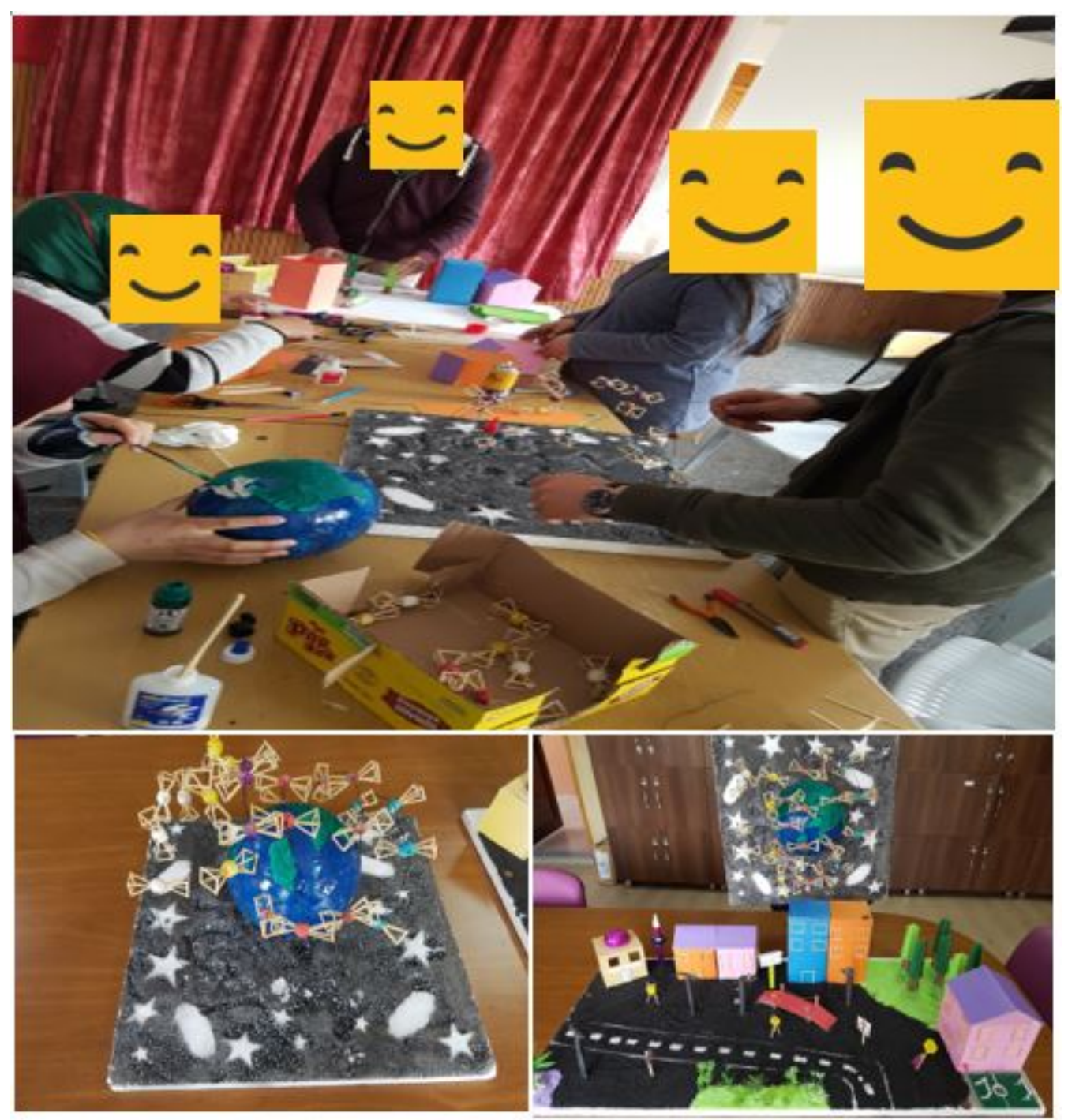

Şekil 5. GPS sistemi materyal çalışması

Benzer şekilde; Uzunluk, alan, hacim birimleri ve aralarındaki dönüşümleri belirtmek için oyuncak bir araba materyali hazırlanmıştır. Bunun sebebi arabanın mekanizmada yukarıya doğru 
çıkarken yavaş gideceği mantığıyla, birimler arasındaki dönüşümlerde de üst basamağa doğru gidildikçe bölme işlemi yapılacağını belirtmektir.

Derece açı birimi kavramlarını belirtmek için sınıf kapısından faydalanılmış, sınıf kapısı açıldıkça kapı ile duvar arasında kaç derecelik bir açı meydana geldiği uygulamalı bir şekilde gerçekleştirilmiştir. Kapı aralığı artırıldıkça aradaki açı artacak, kapı aralığı azaldıkça da açı azalacaktır. Bu materyal kullanılarak derece açı birim sistemi rahatlıkla öğrencilere kavratılacak, öğrenciler, grad açı birim sistemi ile derece açı birimi sistemi arasındaki farklılıkları daha kolay bir şekilde ayırt etme firsatı bulacaktır.

Ölçek kavramını öğrencilere kalıcı olarak aktarabilmek için okul binasının iki kez çelik şerit metre ile öğrencilere ölçümü yaptırılmıştır. Elde edilen sonuçlar kullanılarak ölçülen değerler 1:100 ölçekli maket tasarıma dönüştürülmüştür. Buradaki amaç hem ölçek kavramını öğrencilere öğretmek, hem de 1:100 ölçekli bir haritada oluşabilecek hata miktarının arazide kaç metrelik bir hataya tekâmül edeceğini görmektir.

Elektronik uzaklıkölçer parçaları ve işlevleri belirtmek için maket elektronik uzaklıkölçer materyali geliştirilmiştir. Materyal elektronik alet parçalarını, her bir parçanın ölçmede hangi işlevi ifade ettiğini, elektronik alette dikkat edilmesi gerekenleri öğrencilere maket üzerinde anlatmak amacıyla tasarlanmıştır.

Bir yol platformunda, araçların savrulmasını önlemek amacıyla yapılan dever uygulamasını öğrencilere aktarmak amacıyla maket bir yol materyali hazırlanmıştır. Öğrencilerde kavram yanılgısına sebebiyet verdiği gözlemlenen bu uygulama basit malzemeler kullanılarak öğrencide kalıcı hale getirilmiştir.

Nivelman nokta tesisi materyal çalışması ile arazide nivelman bronzu tesisi yapılmıştır. Bu anlamda çalışmada yer alan öğrenciler öncelikle nivelman bronzunun ebatlarını BÖHHBÜY'den (Resmi Gazete, 2005) alarak demirci atölyesinde üretmişlerdir. Nivelman tesisi yerden yüksekliği yaklaşık $50 \mathrm{~cm}$ olacak şekilde okul duvarına sabitlenmiştir. Tesis yerleştirildikten sonra nivelman noktasının numarası için mukavva ile şablon oluşturulmuş ve kırmızı yağlı boya boyanmıştır.

Nirengi nokta tesisi pilye materyal çalışmasında öncelikle pilye tesisinin yapılacağı alan belirlenmiştir. Bu alan mümkün olan en çok detayı görecek şekilde seçilmiştir. Yaklaşık 1 metrekare genişliğinde ve $50 \mathrm{~cm}$ derinliğinde bir çukur açılmıştır. Çukurun etrafına parke taş döşenmiştir. Pilyenin sağlamlığını artırmak amacıyla tahta bir parçaya beş adet demir çubuk sabitlenerek, boru kalıbının içine yerleştirilmiştir. Pilye yeşil yağlı boya ile boyanarak, numaralandırılmıştır. Ayrıca pilyenin coğrafi enlemi, boylamı ve denizden yüksekliği de levhaya yazılmıştır. 


\section{Bulgular}

\subsection{Eş Yükseklik Eğrili Materyal Çalışmasından Elde Edilen Bulgular}

Eş yükseklik eğrileri, onların yükselti basamaklarını ve yükselti basamaklarının olması gereken renkleri gösteren materyal çalışmasında öğrencilerin daha önce üç boyutlu arazi yapısından, iki boyutta bulunan eğri çizimi arasındaki ilişkiyi kavramada ki yanılgılar bu materyalin yaptırılmasıyla giderilmiştir.

Öğrencilerin materyalleri oluşturma aşamasını en başından sonuna kadar kendilerinin yapması, konuyu kavramada etkili olan en önemli durumdur. Materyalin her bir aşamasını öğrencinin kendisinin yapması ve bizzat konuyu yaşayarak öğrenmesi hem öğrenmeyi kalıcı kılmış hem de öğrenci de özgüven oluşturmuştur. Ayrıca materyali oluşturma da verilen uğraşının öğrenciyi motive ettiği ve öğrenmeyi eğlenerek, severek yaptığı gözlemlenmiştir.

Öğrenci bu materyal ile ayrıca eş yükseklik eğrilerinin gösterilme biçimlerinden biri olan renklendirme yöntemini de öğrenmiştir. Bu kapsamda; 0-200 m açık yeşil, 200-500 m yeşil, 5001000 m sarı, 1000-1500 m turuncu, 1500-2000 m açık kahverengi, 2000 m ve yukarısı kahverengi renkte olacak şekilde materyali kuralına uygun şekilde tasarlamış ve olması gereken yükseklik aralıklarını materyal üzerinde göstermiştir. Ayrıca deniz mavi renkte ve olası buzullara karşı materyalin tepe noktası beyaz renkle ifade edilmiştir.

Öğrencinin daha önce anlamakta zorlandığı her eş yükseklik eğrisi kendi içinde aynı yüksekliktedir özelliğini materyal üzerinden giderdiği gözlemlenmiştir.

\subsection{Detay Ölçmeleri ve Harita Çizim Özel İşaretleri Materyal Çalışmasından Elde Edilen}

\section{Bulgular}

Detay ölçmeleri ile bu konuyla bağlantılı çizim özel işaretlerinin bir bütün olarak irdelendiği çalışmada daha önce öğrencide oluşan detay noktalarının nasıl ölçülmesi gerektiği, detay noktalarının ölçümünde hangi ayrıntıların yer alması konusu ve bunların harita çiziminde semboller nasıl ifade edilmesi gerektiğinin anlaşılmasında yaşanılan problemler şekil 6'da ki materyal ile ortadan kalkmıştır.

Her bir arazi detayının üç boyutlu olarak öğrenciler tarafından yapılması ve aynı detaya ait çizim veya sembol ile ifade edilen ayrıntının haritada nasıl çizilmesi veya yerleştirilmesi gerektiği materyal üzerinden rahatça okunabilir hale gelmiştir. Her öğrenci üç boyut ve iki boyut arasındaki ilişkiyi kavramıştır. 
Üç boyutlu materyal üzerine poligon ve nivelman noktası da konulmuştur. Detay noktalarının ölçülmesinde poligon noktalarından görünemeyen yerler olduğu zaman, elektronik uzaklıkölçer ile kör poligon noktası atılması gerektiğini de öğrenci ayrıca materyal üzerinde öğrenmiştir.

Çalışma kapsamında öğrencileri araziye çıkarmadan da konuyu öğretebilme imkânı sağlanmıştır. Örneğin yağışlı ve ölçüm yapılması güç bir havada dışarıda anlatılması gereken bu konu sınıf ortamında da rahatlıkla anlatılır hale gelmiştir.

Materyal üzerinde ayrıca röper ölçü krokisinin nasıl alınması gerektiği de anlatılabilmiş ve öğrenciler materyal üzerinden araziye çıkmadan röper ölçü krokisi düzenleyebilmiştir

Materyal kapsamında çöp şiş, yapıştırıcı ve çeşitli malzemeler kullanılarak oluşturulan harita çizim özel işaretlerinin öğrencilerin kendilerinin yapması bu işaretlerin anlamlarını rahat bir şekilde aklında tutmalarını sağlamıştır. Öğrenilen bilgi bu uygulama ile kalıcı hale gelmiştir.

Yapılan bu çalışmalara ek olarak konunun pekiştirilmesi amacıyla öğrencilere şekil 7'de ki oyun materyali geliştirilmiştir. Bu materyal ile hangi detayın hangi sembol veya işaretle gösterildiğini öğrencilerin öğrenip öğrenemediğinin tespiti yapılmıştır. Bu kapsamda öğrenciler sırayla tahtaya kaldırılmış ve fotoğraflardaki arazi detayları ile bu detayın haritada olması gereken çizime ait numarayı harita iğnesi ile tabloda işaretlemiştir. Yapılan gözlemlerde öğrencilerin başarılı oldukları tespit edilmiştir.

\subsection{GPS Sistemi Konulu Materyal Çalışmasından Elde Edilen Bulgular}

GPS sistemini oluşturan materyal çalışmasında özellikle anlaşılmasında güçlük yaşanan ve yanılgılara düşülebilen, GPS ölçme sisteminin mantığı ve yörünge düzlemi konusundaki eksikliklerin giderilmesine çalışılmıştır. Bu anlamda köpük üzerine 6 tane demir teli yardımıyla yörünge oluşturulmuş ve plastik topun etrafına döşenmiştir. Böylece öğrenci 6 yörünge düzlemini ve her yörünge üzerinde yer alan 4 adet uydu sayısını net bir şekilde görmüş ve öğrenmiştir.

GPS sisteminin üç boyutlu bir koordinat elde edebilmesi için en az 4 uydu görmesi gerektiği, GPS sisteminin her durumda sinyal alamadığı, tünel, yüksek binalar ve yüksek ağaçlıklı alanlarda bu sinyalin kesintiye uğradığını da yine bu materyal üzerinde öğrenci gözlemleyebilmiştir. Böylece hayal ederek anlamaya çalıştı̆̆ konuyu, maket üzerinde öğrenebilir hale gelmiştir.

Sabit GPS ve kinematik GPS ölçüm yöntemi de yine materyal üzerinden anlatılmış ve öğrenciler tek tek tahtaya kaldırılarak, öğrendiklerinin tekrarı niteliğinde bu konuları sınıfa kendileri anlatmıştır. Öğrencilerin meraklı oldukları ve konuyu öğrenme istekleri tespit edilmiştir. 


\section{Sonuç ve Öneriler}

Haritacılık meslek olarak çok eskilere dayanan bir miras ve bilgi birikimine sahiptir. Son yıllarda hızlı şekilde gelişen teknolojik imkânlar ise meslek alt uzmanlık alanlarının uygulamalarını kolaylaştırmakla birlikte mesleği farklı alanlara yönlendirmektedir. Bu farklı alanlar da mesleği farklı eğitim seviyelerinde yetişmiş insan kaynağı icra etmektedir. Bunlar haritacılık mesleğinin icrası ile uğraşırken bu insan kaynağını yetiştiren eğitim kurumları da hem mesleğin ve hem de eğitim-öğretim sisteminin daha da iyi noktalara getirmekle uğraşmaktadır. Harita eğitimi veren kurumlar sırasıyla orta öğretim de Mesleki ve Teknik Anadolu Liselerinde harita tapu kadastro bölümleri, üniversitelerin meslek yüksekokullarında harita ve kadastro programları ve mühendislik fakültelerinde harita mühendisliği bölümleri ile yüksek lisans ve doktora eğitimi verebilen üniversitelere bağlı enstitüler yer almaktadır. Bu eğitim kurumlarında, hem sektör için insan kaynağı ihtiyacı karşılanmakta ve hem de bilimsel araştırmalar yürütülmektedir. İnsan kaynağının iyi yetişmesi ve mesleki konulara hâkim olması sektör için büyük önem arz etmektedir. Bunun başta eğitim kurumları ile sağlanması, devamında ise yaşam boyu öğrenme gibi kavramlarla sürekli hale getirilmesi gerekliliği bilinmektedir. Burada eğitim kurumları öğrencilere mesleki konuları verirken öğrenci merkezli ve yenilikçi yöntemler kullanmalıdır. Eğitim biliminin konusu olan bu yöntemler sayesinde, daha kaliteli insan kaynağı yetiştirileceği aşikârdır.

Günümüzde haritacılık eğitimi öğretmen merkezli kalmaktadır. Öğrenci merkezli ve öğrencinin daha aktif olduğu bir eğitim ortamı verimi arttırabilir. Bu eksikliğin giderilmesi, eğitim kurumlarında eğitim verecek olanların mesleki konularına hâkim olması yanında, yeterli pedagojik formasyonu alması gereklidir. Ayrıca, öğretim ilke ve yöntemlerini iyi özümsemesi gerekmektedir. Buna ilaveten eğitimciler, öğrencilerde kalıcı izli öğrenme oluşturabilme amaçlı ne tür çalışmalar yapılabileceği hakkında bilgi sahibi de olmalıdırlar. Konu kavrama düzeyini artırıcı ve bilgi eksikliklerini giderici materyal kullanımına önem verilmelidir. Bu materyallerin geliştirilmesi ve etkisi analiz edilerek ne kadar başarılı oldukları da test edilmelidir.

Her ders için çeşitli öğretim yöntem ve tekniklerinin kullanılması gerekmektedir. Çünkü her insanın zekâ türü aynı değildir. Kimilerinin sözel zekâsı daha güçlü iken, kimilerinin sayısal zekâsı, ritimsel zekâsı, görsel zekâsı daha iyi olabilmektedir. Bu amaçla öğrenme tek bir yöntem ve teknikten oluşmamalı, farklı zekâ türlerinin olduğunu bilerek yöntem ve teknik çeşitliliğinin artırılması sağlanmalıdır. Ayrıca konularla ilgili olarak mümkün mertebe çok ve farklı uygulamalar yaptırılmalı ve bunlar öğrenci merkezli uygulamalar olmalıdır. Tüm bunlar göz önünde bulundurulduğunda verilen eğitimin kalitesi artacak, öğrencilerin öğrenme konusundaki eksiklikleri giderilmiş olacak, aynı zamanda kalıcı öğrenen ve öğrendiğini unutmayan, bilgi eksikliği ortadan kalkmış veya asgari düzeye inmiş bir eğitim anlayışıyla öğrenci yetişmiş olacaktır. 
Yapılan çalışmada 10.sınıf, 11.sınıf ve 12. sınıf öğrencilerinden bazıları örneklem grubu olarak belirlenmiştir. İlk adım olarak zorunlu derslerde yapılan sınavlar analiz edilmiştir. Bazı sorulara verilen yanıtların ortalama başarıları değerlendirilmiştir. Bu başarıların \%50 altında olduğu sorulara ilişkin beceriler materyal geliştirilmesi için seçilmiştir. Materyaller sorumlu öğretmen rehberliğinde alanında uzman nitelikli diğer öğretmenler ve akademisyenler ile birlikte geliştirilmiştir. Geliştirilen bu materyallerin analiz edilmesi için aynı örneklem gruplarına materyallere ilişkin ödevler verilmiştir. Öğrenciler hem materyal geliştirme ve hem de geliştirilen materyali açıklama ve sorulan soruları yanıtlama sonucu performans notu verilmiştir. Ödev notlarının başarısının \%50 üzerinde olduğu materyallerin öğrencilere arzu edilen becerileri kazandırma da etkili olduğu değerlendirilmiştir. Farklı öğretim, yöntem ve tekniklerinin kullanılması, öğrenci merkezli çalışma ve uygulamaların yaptırılması hem öğrenmeyi kolay ve kalıcı hale getirmiş hem de öğrenciler eğlenerek konuları öğrenme imkânı bulmuştur. Bilgi direkt öğretmen tarafından öğrenciye aktarılmamış, ipucu ve güdüleme ile bilgiyi öğrencinin kendisinin elde edebilmesi sağlanmıştır.

Çalışma kapsamında haritacılık mesleğinin temel konuları ele alınarak orta öğretim, ön lisans ve lisans seviyelerinde verildikleri dersler sunulmuştur. $\mathrm{Bu}$ derslerin öğretim ilke yöntem ve stratejileri ile ilişkileri kurulmuştur. Uygulama alanı olarak ortaöğretim kurumları seçilmiştir. Belirli konulara yönelik geliştirilen materyaller öğrencilere uygulanmış ve uygulama sonuçları materyallerin etkin olduğu ispatlamıştır. Araştırma yapacak olan araştırmacılara, özellikle ön lisans ve lisans seviyesindeki derslerde, farklı öğretim ilke ve yöntemlerini kullanmaları ve materyal geliştirmeleri önerilmektedir.

\section{Bilgi}

$\mathrm{Bu}$ çalışma Karadeniz Teknik Üniversitesi Fen Bilimleri Enstitüsü Harita Mühendisliği Anabilim Dalı tezli yüksek lisans programında Doç. Dr. Yakup Emre ÇORUHLU danışmanlığında, Harita Tapu Kadastro Alan Öğretmeni Harita Mühendisi Emre KARAAĞAÇ tarafindan tamamlanan yüksek lisans tezinden geliştirilerek üretilmiştir.

\section{Yazarların Katkısı}

Yazarlar çalışmaya eşit katkıda bulunmuştur.

\section{Çıkar Çatışması Beyanı}

Herhangi bir çıkar çatışması bulunmamaktadır. 


\section{Araştırma ve Yayın Etiği Beyanı}

Yapılan çalışmada araştırma ve yayın etiğine uyulmuştur.

\section{Kaynaklar}

Başer, V., Bıyık, C., ve Demir, O. (2011). Kıyı ve Denizel Alanlarda Harita Mühendisliği Uygulamaları. 7. Kıyı Mühendisliği Sempozyumu, Trabzon.

Başer, V., Bıyık, C., Uzun, B., Yıldırım, V., \& Nişancı, R., (2016). A recommendation of decision-support model based on geographical information systems for generating real estate evaluation maps: kaşüstü/trabzon example. Sigma Journal of Engineering \& Natural Sciences/Mühendislik ve Fen Bilimleri Dergisi, 34(3), 349-363.

Boztoprak T., Demir O., Çoruhlu Y.E. (2017), Harita (Geomatik) Mühendisliği Öğretim Üyelerinin Bölüm, Eğitim ve Öğrenci İlişkileri Hakkındaki Görüşlerinin Değerlendirilmesi, Yükseköğretim ve Bilim Dergisi, 7, 1-11.

Çelik, L. (2007). Öğretim Materyallerinin Hazırlanması ve Seçimi. Öğretim Teknolojileri ve Materyal Geliştirme, Ankara: Pegem Yayıncıl1k.

Çelik, A., ve Şahin, M. (2013). Spor ve çocuk gelişimi. International Journal of Social Science 6(1), 467-478.

Çelikkaya, T. (2008). Yapılandırmacı Yaklaşımın Sosyal Bilgiler Öğretiminde Başarı, Tutum ve Kalıcılığa Etkisi (5.Sinıf Örneği), Doktora Tezi, Atatürk Üniversitesi, Sosyal Bilimler Enstitüsü, Erzurum.

Çepni, S., Ayas, A., Ekiz, D.\& Akyıldız, S. (2008). Öğretim İlke ve Yöntemleri. Trabzon: Celepler Matbaacilik.

Çiçek, S. (2012). Öğretim Yöntem ve Teknikleri, Ankara: Ayrıntı basımevi.

Çilenti, K. (1991). Ĕ̈itim Teknolojisi ve Öğretim. Ankara: Kadığlu Matbaası

Çoruhlu, Y. E., Baser, V. and Yildiz, O., (2021). Object-based geographical data model for determination of the cemetery sites using SWOT and AHP integration, Survey Review, 53(377), 108-121, DOI: $10.1080 / 00396265.2020 .1747843$

Çoruhlu, Y. E. , ve Uzun, B., (2018). Investigation the Accreditation Process and Development an ObjectOriented Database: Case Study for Department of Geomatics Engineerıng. Sigma Journal of Engineering and Natural Sclences, 36(4), 1097-1124.

Çoruhlu, Y. E. , Er Nas, S., Uzun, B., Yıldız, O., \& Şahin, F., (2019a). Vakıflar Kanununun 30. Maddesinin Uygulanması Konusunda Materyallerin Geliştirilmesi. Uluslararası Fen, Matematik, Girişimcilik ve Teknoloji Ë̆itimi Kongresi, 878-887. İzmir.

Çoruhlu, Y. E. , Er Nas, S., Uzun, B., Yıldız, O., \& Şahin, F., (2019b). Harita Mühendisliği Öğrencilerinin Bilgi Eksikliklerinin ve Kavram Yanılgılarının Belirlenmesi: "Vakıf ve Mülkiyet İlişkisi” Örneği. İksad III. Uluslararast Sosyal Bilimler Kongresi, 414-426. Adana.

Çoruhlu, Y. E., Uzun, B., Yııldı, O., \& Şahin, F., (2019c). Harita Mühendisliği Öğrencilerinin Vakıf ve Mülkiyet İlişkisi Üzerine Kavram Yanılgılarının Belirlenmesi, EJONS 6. International Congress on Mathematics, Engineering, Natural and Medical Sciences (Pp.148-158). Adana.

Demirel, Ö. (2007). Alternatif Ders Materyalleri Gelişstirme. Öğretim Teknolojileri ve Materyal Geliştirme, Ankara: Pegem Yayıncilık.

Erden, M. (1997). Sosyal Bilgiler Öğretimi, Ankara: Alkım Yayınevi.

Ertürk, S. (1972). Ĕgitimde program geliştirme, Ankara.

Ergani, K. (2010). İlköğretim 4. ve 5. Sinıf Sosyal Bilgiler Dersi Öğretim Yöntem ve Teknikleri İle Materyal Kullanımına İlişkin Öğretmen Görüşleri, Yüksek Lisans Tezi, Dumlupınar Üniversitesi Sosyal Bilimler Enstitüsü, İlköğretim Anabilim Dalı, Kütahya.

Gong, J., Yue, P., Woldai, T., Tsai, F., Vyas, A., Wu, H., ... \& Musikhin, I. (2017). Geoinformatics education and outreach: looking forward. Geo-spatial information science, 20(2), 209-217.

Gönen, S., ve Kocakaya, S. (2006). Fizik Öğretmenlerinin Hizmet İçi Eğitimler Üzerine Görüşlerinin Değerlendirilmesi, Pamukkale Üniversitesi Eğitim Fakültesi Dergisi.

Karaağaç. E., (2019). Harita Tapu Kadastro Programında Öğrenci Başarısını Arttırmaya Yönelik Materyal Geliştirilmesi, Yüksek Lisans Tezi, Karadeniz Teknik Üniversitesi Fen Bilimler Enstitüsü, Trabzon. 
Kılıç, A. ve Acat, M. B. (2007). Öğretmen adaylarının algılarına göre öğretmen yetiştirme programlarındaki derslerin gereklilik ve işe vurukluk düzeyi. Sosyal Bilimler Dergisi, 17, 21-37.

Kırbaş, A. (2010). İşbirlikli öğrenme yönteminin ilköğretim sekizinci sınıf ögrencilerinin dinleme becerilerini geliştirmesine etkisi, Doktora Tezi, Atatürk Üniversitesi, Sosyal Bilimler Enstitüsü, Erzurum.

Oddens, D. A. M. (2004). Kişilik Nitelikleri Açısından Hollanda'da Mesleki Eğitim İçin Öğretmen Eğitimi Eğilimleri. Mesleki ve Teknik Ĕ̈itimde Öğretmen Eğitimi Uluslararası Konferansı, 37-44. Ankara.

Resmi Gazete, Büyük Ölçekli Harita ve Harita Bilgileri Üretim Yönetmeliği, 9070, Ek 102, 104.

Sönmez, V. (2009). Öğretim Illke ve Yöntemleri, Ankara: An1 yayınc1lık.

Taşpınar, M. \& Atıcı, B. (2002). Öğretim model, strateji, yöntem ve becerileri/teknikleri, Kavramsal boyut. Ë̆itim Araştırmaları, 2(8), 207-215.

Vural, B. (2004). Ĕgitim Öğretimde Teknoloji ve Materyal Kullanımı, Hayat Yayıncılık: İstanbul.

Yanpar, T., Koray, Ö., Parmaksız, R. Ş., Arslan, A. (2006). İlköğretim Öğretmen Adayları Tarafindan Hazırlanan El Yapımı ve Teknoloji Temelli Materyallerin Yaratıcılık Boyutları Açısından İncelenmesi. Kuram ve Uygulamada Ĕ̈itim Yönetimi Dergisi, 12(1), 129-148.

Yanpar, T., (2009). Öğretmen adaylarının portfolyoları üzerinde grup olarak yaratıcılık temelli materyal geliştirmenin etkileri. Eğitim ve Bilim, 34(153).

Yildirim, F., and Baser, V. (2020). Analysis the Geomatics Discipline in Turkey. Sigma Journal of Engineering \& Natural Sciences/Mühendislik ve Fen Bilimleri Dergisi, 38(2), 889-906.

Yue, P., R. Ramachandran, P. Baumann, S. Khalsa, M. Deng, and L. Jiang. 2016. "Recent Activities in Earth Data Science." IEEE Geoscience and Remote Sensing Magazine 4(4), 84-89.

URL-1: http://www.megep.meb.gov.tr/?page=ogretimProgramlari. (Erişim Tarihi: 29/03/ 2021).

URL-2: http://fehimtu.blogcu.com/materyal-tasarimi-hazirlama-ilkeleri/10586224. (Erişim Tarihi: 21/10/2019). 